RADENKO M. MARIĆ, Ph.D. ${ }^{1}$

(Corresponding author)

E-mail: radenko.maric@ef.uns.ac.rs

DRAGAN ĐURANOVIĆ, Ph.D. ${ }^{1}$

E-mail: djuranovic@ef.uns.ac.rs

DANIELA NUŠEVA, Ph.D. ${ }^{1}$

E-mail: nusevad@ef.uns.ac.rs

${ }^{1}$ University of Novi Sad, Faculty of Economics in Subotica

Segedinski put 9-11, 24000 Subotica, Republic of Serbia
Transport Logistics

Preliminary Communication

Submitted: 7 Mar. 2017

Accepted: 11 Oct. 2017

\title{
KEY INDICATORS OF PHYSICAL DISTRIBUTION OF GOODS: A CASE STUDY OF THE WESTERN BALKANS
}

\begin{abstract}
The aim of this paper is to improve the process of physical distribution of consumer goods in the Western Balkans region through defining and analyzing key indicators of physical distribution. Theoretical research identified the most important indicators that affect physical distribution, such as: transport costs, quality of delivery, condition of vehicles, customer relations, and institutional/regulatory factors. The empirical study was conducted on a sample of 166 respondents in the distribution centers and transport companies and 146 end customers. Multiple regression analysis defined the individual contribution of each of these indicators to the process of physical distribution of goods. A comparison of results between the Western Balkan countries that are EU member states and those that are non-EU countries showed statistically significant differences in the impact of these indicators. Based on the obtained results, a model of physical distribution of consumer goods was presented. The results show to managements of distribution centers and transport companies which indicators should be developed to ensure timely and complete delivery of goods according to the 7P concept and thereby create a base of satisfied and loyal end users of transport services. Recommendations for future research are provided in the paper.
\end{abstract}

\section{KEY WORDS}

road freight transport; distribution centers; physical distribution of goods; retail;

\section{INTRODUCTION}

The processes of international expansion of companies' activities and globalization of business, as well as the formation of regional integration, have caused an increase in the volume of production and trade at the global, regional and national level, and therefore major changes in the management of supply chains. In his study, Cristopher [1] emphasizes that the supply chains that represent the input-output structure of business activities, starting from the procurement of raw materials and ending with the physical distribution of goods, have suffered big changes in the last decade, and therefore it is necessary to increasingly adapt all structural activities to the needs of the market and end users. Other research [2] confirms that holders of logistics activities are required to perform more transactions, in smaller quantities, in less time, at a lower cost, and with a higher level of accuracy. According to the results of the research conducted by Manders et al., [3] the main task of all participants in the supply chains is to be part of a flexible system, which will provide and deliver proper goods, to proper place, at the proper time, in the proper quantity, in the proper condition, in the proper package, and at proper costs (7P concept). This is the result of all individual services in the supply chain, from packing and labeling services, the formation and disassembly of cargo units, storage, stock keeping, transshipment, transportation, information, and physical distribution to end users [4]. Modern approach to supply chain management and logistics management includes management strategies, which should not only observe cost efficiencies, but also analyze physical, ecological, historical, and other factors, which are equally burdening the process of physical distribution.

Numerous studies [5] mention that the most important link in the supply chain that contributes to the timely, complete, and cost-efficient physical distribution of goods is an efficient and reliable transport of goods, i.e., the logistics trinity: the distribution center, the end customer and JIT (Just in Time) delivery. Eckhardta and Rantalab [3] conclude that a transport system provides transfer of products along the supply chain from loading to the unloading place and is one of the key factors affecting the overall profitability of the distribution centers and the creation of cost-efficient and customer-responsive physical distribution. Hence the need for analysis and research on indicators that affect the transport of goods in the supply chain from logistics centers to end users. In addition, this is a rapidly growing economic activity, with data showing that due to the rapid development of trade and retail networks in the Western Balkans, the road transport of consumer goods dominates, and, 
according to the latest research and with regard to the total amount of goods transported in the region of the Western Balkans, accounts for over 50\% (Serbia $7.969 t_{(000)}$ or $50.6 \%$; Croatia $66.491 t_{(000)}$ or $48 \%$, Slovenia $40.857 \mathrm{t}_{(000)}$ or $48.2 \%$, Bosnia and Herzegovina $5.770 t_{(000)}$ or $51 \%$, etc.). However, the share of revenues from road freight transport in the GDP structure of the Western Balkans in 2014 ranged between 3\% and 5\% (Statistical Yearbooks Cro/Srb/Slo/ $\mathrm{Mng} / \mathrm{Mac} / \mathrm{B} \& \mathrm{H})$. The reason behind the research of road transport of consumer goods lies in the fact that this form of transport in the process of physical distribution of consumer goods is the most common in Serbia (98\%), Macedonia (95\%), and Bosnia and Hercegovina (99\%), where other modes of transport and supply of the retail network are almost impossible due to underdeveloped infrastructure. Another reason for conducting the research on physical distribution and road transport in the Western Balkans is the fact that it is a specific geopolitical area that includes EU member states and countries that are in the process of joining the EU, making this region suitable for comparison of data and analysis of results between economically and commercially organized systems belonging to the EU and countries in transition.

Bearing in mind the previously described aspects, the subject of this paper is the analysis of the road transport of consumer goods, which is performed between logistics centers and end customers (retailers) as a single link (phase) of the supply chain. The aim of the research is to - based on the definition and analysis of the indicators that contribute to and determine physical distribution of goods in the Western Balkans - present proposals and recommendations on which indicators should be developed for a more efficient and cost-effective process of physical distribution. The aim of the research is to compare research results between the Western Balkan countries that are EU member states and those that are non-EU countries, in order to determine whether there are differences in the impact of the indicators on road transport of consumer goods between the countries that are more developed and better organized in terms of infrastructure and legislature (Slo \& Cro) and transition countries (Srb, B\&H, Mng \& Mac). Due to uneven levels of development of transport infrastructure between the mentioned countries, in order to alleviate the lack of comparative research, the distribution centers selected from the sample are those located near large city centers where the traffic network and infrastructure connections with retailers are approximately at the same level of development in all analyzed countries. The results obtained should be an indication to managements of transport companies and distribution centers which indicators they should invest in, develop, and strengthen so that end customers get timely and complete deliveries of required goods.
The paper consists of the following sections. After the introduction, which explains the reason and the subject of the research, the Theoretical Background section defines the groups and subgroups of indicators affecting the physical distribution of consumer goods, i.e., transport between distribution centers and end customers. The aim of the research, the hypotheses, sample description, the measurement variables, and research procedures are given in the Research Methodology section. The Results section shows and interprets the obtained results, and provides testing of the research hypotheses. A discussion of the results, with a particular emphasis on the differences in the research results between the EU countries and non-EU countries, as well as a presentation of a formula for physical distribution of goods in the Western Balkans, is provided in the Discussion section. The conclusions of this study and suggestions for future research are presented in the Conclusion section.

\section{THEORETICAL BACKGROUND}

The development of information and telecommunication technology, transport innovation, increased competitiveness, and growing demands of the market and consumers lead to constant changes in the business of logistics centers and their growing orientation towards creating a package of additional services and meeting the needs of end customers. The research in this paper relates to distribution centers and logistics centers that are focused on two processes: the storage time process and the transport process. Authors [6] usually define them as the warehouses where stocks of materials and goods are stored on their way through the supply chain to the end consumer. They can be specialized for a particular service, product, or market area but can also cover a far wider scope of business functions. Although the influence and significance vary between different distribution centers, research shows that due to structural changes in the retail sector (formation of supermarket networks that require a continuous supply of goods) [7] the transport system is one of the most important components of the logistics system [6]. Road transport system in retailing, as an integral part of the physical distribution process, should provide a timely, complete, safe, and economically viable (7P concept) transfer of goods from the place of loading (distribution center) to the place of unloading, i.e., end customer (retailer).

Previous research in the global market, such as the study conducted by Antún et al., on distribution centers in Mexico in 2010, dealt with the problem of choosing the most optimal location of distribution centers that would reduce costs and improve the physical distribution process based on the 7P concept [8]. Other research, e.g. Oke and Gopalakrishan from 2009, emphasizes the importance of identifying and defining 
risks in the supply chain and minimizing them, leading to a more efficient final distribution [9]. The research done by Ivanova et al. in 2014 points to the importance of planning the most optimal route of delivery of goods to end users [10]. On the other hand, some pilot studies, such as Guan and Rehme's study conducted in 2012 in the UK [11], show that it is economically more cost-effective for all participants in the supply chain to transform producers into distributors, which will more effectively and reliably meet the demands of retailers. The results of the study done by Cai et al., conducted in China in 2010 [12], show that the efficiency of physical distribution of goods depends on trust in the distributor, its flexibility, and the ability to quickly adjust the transport and delivery of goods to the demands of end customers.

The results of the research done by Chaea [13] show that transport companies need to focus on a small list of key performance indicators (KPIs) that are critical to managing the physical distribution process and that will ensure the financial sustainability of companies, such as transport costs and customer service (timely and complete delivery). As key performance indicators in the process of physical distribution of goods, the research done by Dumitrache et al. in Romania in 2015 [14] emphasizes the quality and speed of delivery, business costs, and institutional factors. On the other hand, Cai et al. [12] include customer satisfaction and building of long-term relationships (CRM) with end users of physical distribution services among the most important KPIs in the supply chains of retail companies.

In the Western Balkans region, academic research regarding the mentioned issues was limited. Researchers paid little attention to the analysis of road transport of consumer goods and the physical distribution process. They analyzed only individual indicators, therefore the importance of this paper is in its systematization, definition, and unified analysis of the impact on the physical distribution of consumer goods. Indicators should be first classified into broader groups, and then their subcategories are determined within a given group. Based on the above theoretical research, the five main groups of indicators are: costs of transport [13], quality of delivery $[13,14]$, condition of vehicles [15], customer relations [11, 12], and institutional/ regulatory factors [8]. Identification and analysis of these indicators are essential to the successful operation of distribution centers based on the 7P concept, where their continuous monitoring and measurement are necessary, as well as a continuing search for ways to improve them.

Costs of transport are among the most important costs and average one third of the overall structure of logistics costs [13]. In this paper, the following costs are separated and analyzed: the overall transport costs, transport costs per kilometer (tkm), cargo insurance costs, vehicle insurance costs, costs of order processing (e.g. IT support), and salary costs. Road transport of consumer goods, and therefore costs of road transport, are particularly important in the Western Balkans countries due to poorly developed infrastructure of road transport and non-existing or poor infrastructure of other transport modes. In particular, poorly developed rail and waterway infrastructures in Serbia, Macedonia, and Bosnia and Herzegovina further highlight the demands for the improvement of road transport and efficient cost management, which continue to grow due to the increased transit of goods through the countries of the Western Balkans, the rapid development of the retail network, the new demands of customers and markets, which have also influenced significant changes in the structure and organization of supply chains.

Quality of delivery, the modern conditions of doing business, and the growing demands of the market and end consumers emphasize the need for timely and complete delivery of consumer goods [13, 14]. Assessment of end-user satisfaction with transport services depends on indicators such as total delivery time, loading and unloading times, timeliness of delivery, percentage of losses and damages, vehicle capacity utilization, number of mistakes in the delivery, and special equipment. Delivery quality should aim at achieving perfect order performance, which means achieving the highest percentage of delivery timeliness (percentage of orders that will arrive at the final destination at the agreed time between the buyer and the shipper), delivery completeness (percentage of orders delivered with all lines and units), damage-free delivery (percentage of customer orders delivered in good and usable condition), and accurate documentation (percentage of the total number of orders for which the customer received the correct invoice and other necessary documents). A detailed discussion and analysis of the impact of this indicator is an essential part of a comprehensive analysis of physical distribution of consumer goods.

The results of the studies [15] show that the condition of vehicles directly affects delivery times for goods and finished products. Distribution centers and transportation companies need to minimize the risk of failure of vehicles during transport and ensure maximum utilization of vehicle capacity through their continuous depreciation, regular service, and maintenance. This group of indicators includes: repair and maintenance of vehicles, vehicle age, vehicle defects, and investment in new vehicles.

In terms of customer relations, to evaluate the relationship between transport companies and customers, as well as customers' satisfaction with the service provided, it is necessary to thoroughly analyze the values of the relationship for both sides. One of the main goals is to ensure long-term business 
relationships that contribute to the stability of operations of distribution centers and transport companies $[11,12]$. The following indicators are analyzed as particularly significant: communication with customers, long-term relations with customers, number of major customers, counseling services, and the number of customers lost due to delivery delays.

Institutional/regulatory factors, underdeveloped transport infrastructure (particularly in non-EU countries), difficult cooperation between public and private sectors, insufficient funding sources, time-consuming and costly bureaucratic procedures, inadequate application of modern standards and technologies, etc. hamper the efficiency of road transport in the Western Balkans countries. The quality of physical distribution of consumer goods depends largely on the above mentioned external factors over which transport companies and distribution centers have limited control. Those are the following indicators: infrastructure, easy access to retail, charges, tariffs and tolls, transport safety, and compliance with standards.

\section{RESEARCH METHODOLOGY}

The aim of the research and research hypotheses. The aim of the research is to analyze the impact of indicators (transport costs, quality of delivery, condition of vehicles, customer relations, and institutional/regulatory factors) on physical distribution of consumer goods, i.e., transport and delivery of goods between distribution centers and end customers (retail facilities) in the Western Balkans, with special emphasis on the comparison of research results between the countries in the European Union (Slo and Cro) and the nonEU countries (Srb, Mng, B\&H, and Mac). The task is to determine which indicators have a statistically significant impact and whether their impact varies depending on the region where transport is performed, as well as whether the satisfaction with timely and fully delivered quantity of consumer goods increases the loyalty of end users (retailers). In this context, the first research hypothesis $\mathrm{H}_{1}$ reads: indicators like transport costs, quality of delivery, condition of vehicles, customer relations, and institutional/regulatory factors statistically significantly influence the physical distribution of consumer goods in the countries of the Western Balkans. The first hypothesis can be explained by several auxiliary hypotheses reading as follows: $\mathrm{H}_{1 \mathrm{a}}$ - economically justified high transport costs statistically significantly influence the physical distribution of consumer goods in a positive direction. $\mathrm{H}_{1 \mathrm{~b}}$ - timely and full quality of delivery statistically significantly influences the physical distribution of consumer goods in a positive direction, $\mathrm{H}_{1 \mathrm{c}}$ - good condition of vehicles statistically significantly influences the physical distribution of consumer goods in a positive direction, $\mathrm{H}_{1 \mathrm{~d}}$ - good customer relations statistically significantly influence the physical distribution of consumer goods in a positive direction, and $\mathrm{H}_{1 \mathrm{e}}$ - developed institutional/regulatory factors statistically significantly influence the physical distribution of consumer goods in a positive direction. The second hypothesis, $\mathrm{H}_{2}$, relates to the satisfaction of end users of the physical distribution service and it reads: satisfaction with the process of physical distribution of consumer goods positively affects the loyalty of end users. The mentioned research hypotheses are illustrated by the following model of research (Figure 1).

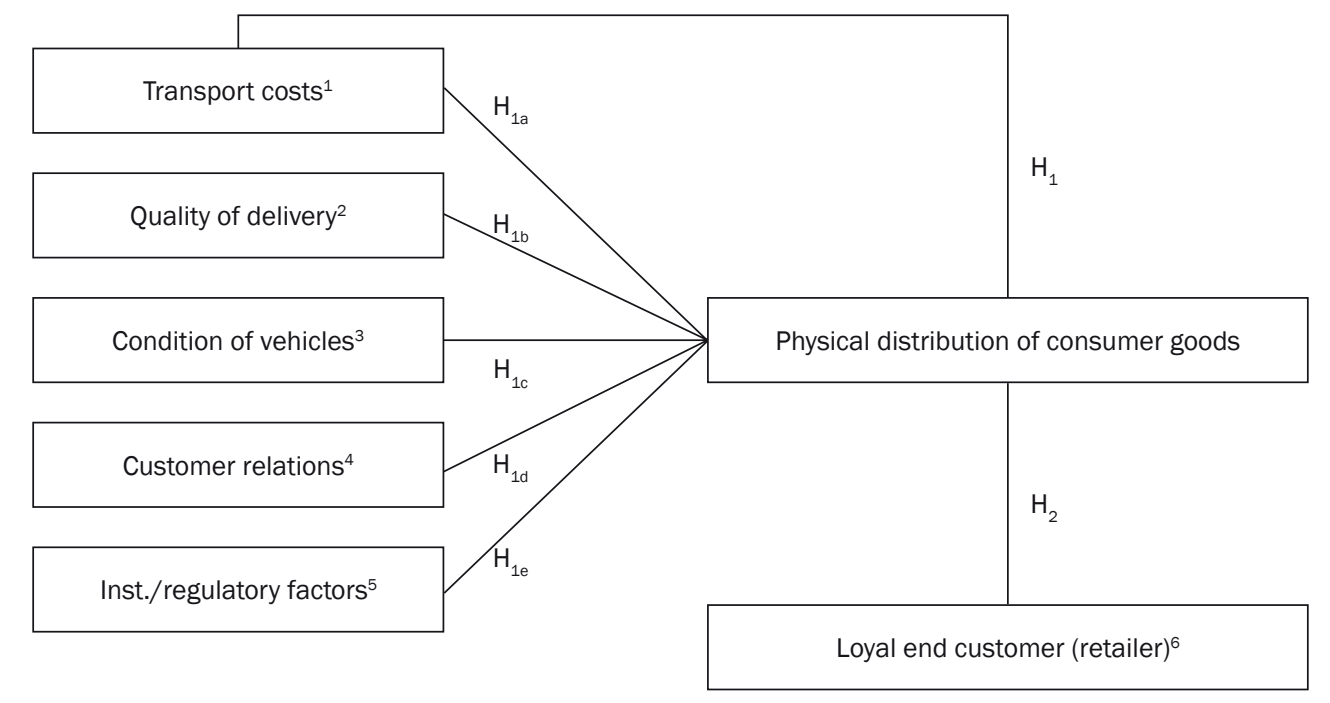

Figure 1 - Research model

${ }^{1}$ Transport costs were tested with 6 items; ${ }^{2}$ Quality of delivery was measured by 7 items; ${ }^{3}$ The condition of vehicles was tested with 4 items; ${ }^{4}$ Customer relations were tested with 5 items; ${ }^{5}$ Institutional / regulatory factors were tested with 5 items; ${ }^{6}$ End customer loyalty was measured with 3 items. 
Variables and measurement scales. The research included several variables for confirming or rejecting the hypotheses. For analyzing the first research hypothesis, whether a tested country of the Western Balkans belonged to the European Union was selected as an independent grouping variable, while transport costs, quality of delivery, the condition of vehicles, customer relations, and institutional/regulatory factors were chosen as independent interval variables of measurement. The dependent variable is the physical distribution of consumer goods, which describes the performance of transport and physical distribution of goods. It was examined with three items concerning the timeliness of delivery, delivery flexibility, and the number of delays in delivery. The items are five-fold Likert type and express the frequency of the examined "behavior" in the physical distribution of goods. For analyzing the second research hypothesis, whether a tested country belonged to the European Union was chosen as an independent grouping variable, timely delivery of goods, flexibility/extraordinary requirements of customers and mistakes in delivery were selected as independent interval variables of measurement, while satisfaction and loyalty of end customers were chosen as dependent variables. Belonging to the group, i.e., membership in the EU, was determined based on the country in which the company operates. Croatia and Slovenia are European Union member states, while Serbia, Bosnia and Herzegovina, Macedonia, and Montenegro are in the process of joining the EU. Evaluation of independent variables, i.e., indicators affecting the physical distribution of consumer goods was performed by a questionnaire containing 27 entries (sub-indicators). Respondents were requested to express their agreement with items on a five-point Likert scale (using a 1-to-5 rating scale, estimate how the mentioned indicator affects the physical distribution of consumer goods, where a lower value indicates a lower estimate of the statistically significant impact of a particular indicator on the delivery of goods). Based on the initial set of items, 5 dimensions were formed - transport costs, quality of delivery, condition of vehicles, customer relations, and institutional/regulatory factors. The dimensions were operationalized as the average of responses on the set of indicators that describe them. Identical methodology was applied to a sample of retailers, where independent variables that affect the satisfaction and loyalty of end users of physical distribution were assessed by a questionnaire containing 3 items of Likert type.

The research sample. The research covered 166 respondents employed in distribution centers and transport companies, and they evaluated indicators for the physical distribution of consumer goods. The distribution centers and transport companies covered by the research operate in Serbia (DTS-Delta Transportni sistem, Trans Cargo Logistics, DB Schenker, Milšped, etc.), Montenegro (Montenomax, Voli, Koti Group, etc.), Macedonia (Tinex, Nelt, Pekabesco, etc.), Bosnia and Hercegovina (Gebrüder Weiss, Rail Cargo Logistics, Wurth, etc.), Croatia (Alca, AWT, FAS logistika, M transporti, Orbico, etc.), and Slovenia (TLS, DSV, Lotrans, Gebruder Weiss, etc.). Out of the total number of respondents, $60 \%$ were from the non-EU countries, while $40 \%$ of respondents were from the European Union member states. The second research sample covered employees in the largest retailing chains $(n=146)$ in the Western Balkans (IDEA, Mercator, Delhaize Maxi, Tus, Roda, Tempo, etc.). They evaluated the indicators of satisfaction with physical distribution. The representation of respondents in the sample is shown in the following table (Table 1).

Table 1 - Research sample

\begin{tabular}{|l|c|c|c|c||}
\hline \multirow{2}{*}{} & \multicolumn{2}{|c|}{$\begin{array}{c}\text { Dist. centers \& } \\
\text { trans. companies }\end{array}$} & \multicolumn{2}{c||}{ Retailers } \\
\cline { 2 - 5 } & No. & \multicolumn{1}{c||}{$\%$} & \multicolumn{1}{c|}{ No. } & \multicolumn{1}{c||}{$\%$} \\
\hline \hline Serbia & 29 & 17.4 & 33 & 22.6 \\
\hline $\begin{array}{l}\text { Bosnia and } \\
\text { Herzegovina }\end{array}$ & 33 & 19.8 & 24 & 16.4 \\
\hline Montenegro & 24 & 14.4 & 13 & 8.9 \\
\hline Macedonia & 14 & 8.4 & 19 & 13.0 \\
\hline Croatia & 30 & 18.0 & 29 & 19.9 \\
\hline Slovenia & 36 & 21.6 & 28 & 19.1 \\
\hline Total & 166 & 100.0 & 146 & 100.0 \\
\hline
\end{tabular}

Procedures and statistical analysis of data. The research included people from the lower and middle levels of management in the observed companies. The companies were contacted via an e-mail explaining the purpose and nature of the research and were sent an online questionnaire. The questionnaire was completed anonymously. The research was conducted from November 2016 to February 2017. The data collected in the research was analyzed using the SPSS 20 statistical package. Dimensions and the respondents' answers were described by descriptive statistics. The average values were presented, as well as deviation for each dimension. Impacts of independent variables on dependent variables were examined by multiple regression analysis.

\section{RESULTS}

The research results and tests conducted were first presented at the level of a sample of distribution centers and transportation companies, and then at the level of a sample of end users (retailers). Descriptive statistics described the extent to which respondents agreed that the mentioned groups of indicators statistically significantly influenced the process of physical distribution of consumer goods. Rank 1 expresses the lowest level of agreement, while rank 5 implies 
the highest level of agreement. Descriptive indicators are provided in Table 2, where it appears that respondents show the highest level of agreement with the indicator Transport costs $(M=3.99)$, and the lowest level of agreement with the Condition of vehicles $(\mathrm{M}=3.302)$. In addition to these descriptive indicators, Table 2 shows the descriptive statistics for the variable of physical distribution of consumer goods.

The conducted research seeks to determine in what ways do the identified groups of indicators affect the process of physical distribution of consumer goods, at the level of the total sample, and especially at the levels of the sub-samples of the EU countries and non-EU countries. The use of multiple regression analysis is the most appropriate for testing the correlation between the observed variables, with respect to the applied research methodology, sample size, and the collected data. The Enter method was applied on the total sample, where all independent variables (transport costs, quality of delivery, condition of vehicles, customer relations, and institutional/regulatory factors) are included together in order to predict the dependent variable (physical distribution of consumer goods). The results show that the regression model is statistically significant $(F(160.5)=7,967, p<0.001)$, i.e., the set of tested indicators significantly predicts physical distribution of consumer goods $\left(\mathrm{H}_{1}\right.$ is accepted). It describes $17.4 \%$ of criterion variance. In addition to the total contribution of the set of indicators, the contribution of individual indicators is also tested. Their contribution is provided in Table 3, which presents the regression model of physical distribution of consumer goods.
Based on the data provided, it can be concluded that the criterion variable is statistically significantly predicted by the variables Customer relations $(p=0.000)$, Quality of delivery $(p=0.005)$, and Transport costs $(p=0.027)$. They predict the dependent variable of physical distribution of consumer goods in a positive direction. This means that with their increase the quality of transport of goods between distribution centers and retailers also increases, i.e., timeliness and completeness of physical distribution is increased. On the other hand, the variables of Condition of vehicles $(p=0.582)$ and Institutional/regulatory factors $(p=0.544)$ did not achieve a statistically significant contribution, i.e., according to the respondents, they did not affect the tested criteria. The reason for the weak influence of these two indicators is the fact that it is understood that good condition of vehicles is implied if the mentioned indicators are fulfilled, while the influence of institutional (infrastructure) and legislative factors is limited. Based on the results at the level of the entire sample of the Western Balkans, it can be concluded that auxiliary hypotheses $\mathrm{H}_{1 \mathrm{a}}, \mathrm{H}_{1 \mathrm{~b}}$, and $\mathrm{H}_{1 \mathrm{~d}}$ are accepted, and that indicators of transport costs, quality of delivery, and customer relations have a positive statistical impact on road transport of consumer goods, while hypotheses $\mathrm{H}_{1 \mathrm{c}}$ and $\mathrm{H}_{1 \mathrm{e}}$ are not accepted.

In the sample of the EU member states, the Enter model was used as in the previous testing, i.e., all independent variables were included together in a regression model to predict the dependent variable. The results indicate that the regression model is statistcally significant $(F(60.5)=14.903, p<0.001)$. The included indicators predict a large portion of variance of the

Table 2 - Descriptive indicators of the examined indicators of physical distribution of consumer goods

\begin{tabular}{||l|c|c|c|c||}
\hline & Min. & Max. & Arithmetic mean & Standard deviation \\
\hline \hline Transport costs & 2.83 & 4.67 & 3.9923 & 0.33669 \\
\hline Quality of delivery & 3.00 & 4.57 & 3.8665 & 0.38500 \\
\hline Condition of vehicles & 1.25 & 4.25 & 3.0151 & 0.64179 \\
\hline Customer relations & 2.80 & 4.00 & 3.3988 & 0.31871 \\
\hline Inst./regul. factors & 2.40 & 4.20 & 3.3988 & 0.47762 \\
\hline
\end{tabular}

Table 3 - Individual predictor contributions to the explanation of criterion variable

\begin{tabular}{||l|c|c|c|c|c||}
\hline \multirow{2}{*}{ Model } & \multicolumn{2}{|c|}{ Unstandardized coefficients } & $\begin{array}{c}\text { Standardized } \\
\text { coefficients }\end{array}$ & \multirow{2}{*}{ T } & Sig. \\
\cline { 2 - 5 } & $\mathrm{B}$ & Std. error & Beta & & 0.000 \\
\hline \hline (constant) & 523 & 1.528 & & 3.614 & 0.027 \\
\hline Transport costs & 0.602 & 0.269 & 0.204 & 2.234 & 0.005 \\
\hline Quality of delivery & 0.464 & 0.163 & 0.262 & 2.852 & 0.582 \\
\hline Condition of vehicles & -0.152 & 0.275 & -0.045 & -0.552 & 0.000 \\
\hline Customer relations & 1.277 & 0.304 & 0.359 & 4.198 & 0.544 \\
\hline Inst./regul. factors & -0.117 & 0.192 & -0.049 & -0.608 & 0 \\
\hline
\end{tabular}


criterion variable. Specifically, they explain $51.7 \%$ of the criteria, i.e., half of the variance, which indicates a good quality of physical distribution and timely and complete delivery of consumer goods ( $\mathrm{H}_{1}$ is accepted). Based on the set of five indicators, a large part of the criterion variable can be predicted. In addition to the total contribution of the predictor set, it was also tested how the variables separately "acted", i.e., whether all of them predicted the criterion of physical distribution of consumer goods and in which direction, as shown by the regression model in Table 4.

Based on the tabular data, three variables generate a statistically significant contribution - transport costs $(p=0.001)$, quality of delivery $(p=0.013)$, and customer relations $(p=0.000)$. It is in a positive direction, which indicates that the increase of these indicators is followed with the increase in the criterion variable, i.e., the quality of physical distribution of consumer goods is increased. Auxiliary hypotheses $\mathrm{H}_{1 \mathrm{a}}, \mathrm{H}_{1 \mathrm{~b}}$, and $\mathrm{H}_{1 \mathrm{~d}}$ at the level of the sample of EU countries are accepted. The other included variables did not achieve a statistically significant contribution.

In order to test how the five indicators explain physical distribution of consumer goods, a multiple regression analysis with the Enter model was applied within the subsample of non-EU countries. The indicators included are the same as in the previous testing. Based on these results, it can be concluded that the applied regression model is not statistically significant, i.e., the set of indicators does not statistically significantly contribute to the explanation of physical distribution
( $F(60,5)=1.867, p=0.107)$. This set describes only $4.2 \%$ of variance among the respondents from the countries that are not members of the European Union. The following table (Table 5) provides indicators of individual impacts of the tested indicators (regression model).

Based on such presented results, it is evident that two variables - transport costs and quality of delivery - in the non-EU countries have a positive impact on physical distribution of consumer goods to end users. Since the set of predictors includes indicators that statistically significantly describe the dependent variable but also indicators with low contribution, it is necessary to perform an additional regression analysis based on the Forward method. In this way, the analysis includes only those indicators that generate a statistically significant contribution in terms of its size. The conducted regression analysis is statistically significant $(F(100.5)=4.782, p<0,05)$. However, the regression model describes a small percentage of variance, and this percentage is $7.1 \%$. In other words, by excluding the part of the set of indicators that does not describe the criterion variable, a model was obtained that statistically significantly, although weakly, describes the criteria $\left(H_{1}\right.$ is partially accepted). Table 6 shows significant contributions. These are again transport costs $(p=0.011)$ and quality of delivery $(p=0.025)$, since with the exclusion of other variables their contribution slightly increased. Given that both contributions are in a positive direction, i.e., the increase of these

Table 4 - Individual predictor contributions to the explanation of the criterion variable - the EU countries sample

\begin{tabular}{||l|c|c|c|c|c||}
\hline \multirow{2}{*}{ Model } & \multicolumn{2}{|c|}{ Unstandardized coefficients } & $\begin{array}{c}\text { Standardized } \\
\text { coefficients }\end{array}$ & \multirow{2}{*}{ T } & Sig. \\
\cline { 2 - 5 } & $\mathrm{B}$ & Std. error & Beta & & 0.999 \\
\hline \hline (constant) & -0.004 & 2.117 & & -0.002 & 0.001 \\
\hline Transport costs & 1.025 & 0.300 & 0.309 & 3.421 & 0.013 \\
\hline Quality of delivery & 0.560 & 0.338 & 0.148 & 1.656 & 0.219 \\
\hline Condition of vehicles & -0.254 & 0.205 & -0.111 & -1.241 & 0.000 \\
\hline Customer relations & 2.066 & 0.317 & 0.592 & 6.518 & 0.442 \\
\hline Inst./regul. factors & -0.141 & 0.182 & -0.068 & -0.774 & 0 \\
\hline
\end{tabular}

Table 5 - Individual predictor contributions to the explanation of the criterion variable - the non-EU countries sample

\begin{tabular}{||l|c|c|c|c|c||}
\hline \multirow{2}{*}{\multicolumn{1}{|c|}{ Model }} & \multicolumn{2}{|c|}{ Unstandardized coefficients } & $\begin{array}{c}\text { Standardized } \\
\text { coefficients }\end{array}$ & \multirow{2}{*}{ T } & Sig. \\
\cline { 2 - 4 } & $\mathrm{B}$ & Std. error & Beta & & 0.003 \\
\hline \hline (constant) & 6.672 & 2.153 & & 3.099 & 0.031 \\
\hline Transport costs & 0.968 & 0.443 & 0.250 & 2.185 & 0.035 \\
\hline Quality of delivery & 0.678 & 0.317 & 0.222 & 2.143 & 0.999 \\
\hline Condition of vehicles & -0.001 & 0.399 & 0.000 & -0.002 & 0.907 \\
\hline Customer relations & 0.059 & 0.507 & 0.015 & 0.117 & 0.902 \\
\hline Inst./regul. factors & 0.037 & 0.302 & 0.015 & 0.123 & 0.902 \\
\hline \hline
\end{tabular}


Table 6 - Individual predictor contributions to the explanation of the criterion variable - sample of non-EU countries

\begin{tabular}{||l|c|c|c|c|c||}
\hline \multirow{2}{*}{ Model } & \multicolumn{2}{|c|}{ Unstandardized coefficients } & $\begin{array}{c}\text { Standardized } \\
\text { coefficients }\end{array}$ & \multirow{2}{*}{ T Sig. } \\
\cline { 2 - 5 } & $\mathrm{B}$ & Std. error & Beta & & 0.001 \\
\hline \hline (constant) & 6.843 & 1.956 & & 3.498 & 0.011 \\
\hline Transport costs & 0.999 & 0.387 & 0.258 & 2.584 & 0.025 \\
\hline Quality of delivery & 0.693 & 0.305 & 0.227 & 2.271 & 0.025 \\
\hline
\end{tabular}

indicators is followed by the increase of the criterion variable, it can be concluded that this method of testing confirms the auxiliary hypotheses $\mathrm{H}_{1 \mathrm{a}}$ and $\mathrm{H}_{1 \mathrm{c}}$.

The testing based on multiple regression analysis shows that the first research hypothesis $\mathrm{H}_{1}$ is accepted at the level of the entire sample of the Western Balkans (indicators describe $17.4 \%$ of criterion variance) and subsample of the EU countries (indicators describe $51.7 \%$ of criterion variance), while at the level of the subsample of non-EU countries it is partially accepted (indicators describe $7.1 \%$ of criterion variance), which leads to the final conclusion that the indicators transport costs, quality of delivery, condition of vehicles, customer relations, and institutional/regulatory factors statistically significantly influence the physical distribution of consumer goods in a positive direction and contribute to the implementation of the 7P concept in the Western Balkans countries. A comparison of the research results shows that transport costs, customer relations, and quality of delivery have a more significant impact in the EU countries, while transport costs and quality of delivery have a statistically significant impact in the non-EU countries. The remaining indicators have a minor impact.

At the level of end-user samples $(n=146)$, loyalty of employees in retail facilities was measured by the physical distribution of consumer goods. The respondents estimated to what extent their satisfaction with the quality of transport, i.e., timely delivery of goods with a minimum number of mistakes, affected their loyalty to the selected transport company and distribution center. Three indicators were evaluated: timeliness of delivery, number of mistakes in delivery, and flexibility/extraordinary requests in delivery. The data and basic indicators of descriptive statistics on a sample of retailers are presented in the following table (Table 7).
The respondents expressed the highest level of agreement with timely delivery of consumer goods $(\mathrm{M}=4.493)$, and the lowest with flexibility in delivery $(\mathrm{M}=3.034)$. As in the previous tests, a multiple regression analysis was performed using the Enter method. The results show that the regression model is statistically significant $(F(150.3)=7.067, p<0.001)$, i.e., the set of tested indicators of satisfaction with the physical distribution of goods statistically significantly affects the loyalty of end users $\left(\mathrm{H}_{2}\right.$ is accepted). It describes $52.4 \%$ of criterion variance. Table 8 presents individual impacts.

Based on the data, it can be concluded that two variables have positive statistically significant contributions - timeliness of delivery $(p=0.000)$ and flexibility in the delivery of transport companies $(p=0.005)$, which means that the increase of these indicators is followed by the increase of satisfaction and loyalty of end users of physical distribution, while the number of mistakes has a negative impact $(B=-0.725$; $p=0.042$ ), i.e., an increase of this indicator is followed by a decrease of customer satisfaction. Comparative research found that identical data are presented in the subsample of EU countries (51.3\% described criterion

Table 7 - Descriptive indicators of tested indicators of retailers' satisfaction with road transport of consumer goods

\begin{tabular}{|l|c|c|c|c||}
\hline & Min. & Max. & Mean & St. deviation \\
\hline $\begin{array}{l}\text { Timeliness } \\
\text { of delivery }\end{array}$ & 2.00 & 5.00 & 4.4931 & 0.7070 \\
\hline $\begin{array}{l}\text { Number } \\
\text { of mistakes }\end{array}$ & 2.00 & 5.00 & 4.0411 & 0.7322 \\
\hline $\begin{array}{l}\text { Flexibility } \\
\text { in delivery }\end{array}$ & 1.00 & 5.00 & 3.0342 & 1.0790 \\
\hline Total & 1.00 & 5.00 & 3.8562 & 0.8782 \\
\hline
\end{tabular}

Table 8 - Individual predictor contributions to the explanation of the criterion variable - sample of retail stores

\begin{tabular}{||l|c|c|c|c|c||}
\hline \multirow{2}{*}{ Model } & \multicolumn{2}{|c|}{ Unstandardized coefficients } & $\begin{array}{c}\text { Standardized } \\
\text { coefficients }\end{array}$ & \multirow{2}{*}{ T Sig. } \\
\cline { 2 - 5 } & B & Std. error & Beta & & 0.999 \\
\hline \hline (constant) & 0.001 & 1.998 & & 0.002 & 0.000 \\
\hline Timeliness of delivery & 2.016 & 0.317 & 0.592 & 6.518 & 0.042 \\
\hline Number of mistakes & -0.725 & 0.422 & -0.309 & -2.421 & 0.005 \\
\hline Flexibility in delivery & 0.562 & 0.161 & 0.278 & 2.824 & 0 \\
\hline
\end{tabular}


variance; timeliness $p=0.001$; flexibility $p=0.004)$ as well as the subsample of non-EU countries $(54.7 \%$ described criterion variance; timeliness $p=0.000$; flexibility $p=0.002)$. The above mentioned implies that satisfaction with timely and complete physical distribution of consumer goods affects the loyalty of end users of transport services in the entire region of the Western Balkans as well as within the individually observed sub-samples (the EU and non-EU countries).

\section{DISCUSSION}

The conducted testing showed that defined groups of indicators make a statistically significant impact on the physical distribution of consumer goods. Based on the applied regression analysis, the following equation of physical distribution of consumer goods can be performed at the level of the entire sample of the countries in the Western Balkans (Equation 1):

$$
\begin{aligned}
y= & 5.52+0.6 x_{1}+0.46 x_{2}-0.15 x_{3}+ \\
& +1.28 x_{4}-0.18 x_{5}
\end{aligned}
$$

In the above equation, $y$ represents a dependent variable called physical distribution of consumer goods, which describes the performance of transport and the physical distribution of consumer goods. The variable was operationalized as the average response of the respondents to questions concerning the efficiency of transport and delivery of goods. The dependent variable remains the same in different equations, except the sample on which it was measured - comprehensive, only EU countries, countries that are in the process of EU accession. In this way, it is possible to isolate the correlation structure in relation to the measurement sample. The variable $x$ is the independent variable, as follows: $x_{1}$ - transport costs; $x_{2}$ - quality of delivery; $x_{3}$ - condition of vehicles; $x_{4}$ - customer relations, and variable $x_{5}$ - institutional/regulatory factors. The independent variables $\left(x_{1}-x_{5}\right)$ were operationalized through a questionnaire containing 25 Likert-type items. Those items described various organizational and external factors that could affect the physical distribution of goods. Each independent variable represents the average response to the 5 items in the questionnaire that describes it in more details. Each independent variable is the interval level of measurement, and the responses range from 1 to 5 , where the lower value implies a smaller impact of a certain variable on the physical distribution of goods.

Acting upon the presented equation should be the guideline to the managements of distribution centers and transport companies on how to improve road transport and provide timely and complete delivery of goods (based on the 7P concept). Improvement of physical distribution means that company managements should ensure a more timely and complete delivery, i.e., develop and promote indicators that have the highest parameter (constant B). According to the aforementioned equation, employees in distribution centers and transport companies are required to work on improving and enhancing customer relations and partners $(B=1.28)$ through: (a) constructive two-way communication and building long-term relationships based on respect of their demands and flexibility in delivery (e.g. change in the quantity, time, delivery location, etc.), (b) professional consulting services, (c) assisting customers in case of lost and late deliveries, (d) financial compensation in the event of unforeseen breakage, damage to packaging, negligent transportation, etc. Improvement of physical distribution includes the correct management and allocation of costs $(B=0.6)$. In order to improve the quality of transport, managers must accurately locate costs and optimize the total costs of transport, which involves: (a) proper classification of jobs, responsibilities and tasks, and, accordingly, salary costs, (b) minimizing the cost per kilometer (selection of the best/shortest/fastest route, avoiding traffic jams, fuel economy, etc.), (c) selection of the best insurance companies for insuring vehicles and goods in transit, (d) optimization of the cost of processing orders through implementation of latest IT technologies, mobile applications, GPS devices, etc. The improvement of physical distribution implies ensuring, in addition to the mentioned indicators, timely and complete delivery, $(B=0.46)$ through: $(a)$ precisely planned time required for loading and unloading of goods in order to reduce the total transport and unloading time, (b) minimizing the number of mistakes in delivery (e.g. mistakes in quantity and type of goods being transported, location, etc.) in order to ensure the completeness of the final delivery, (c) investment in the purchase of special equipment for the improvement of loading and unloading, safety and security of goods in transport, etc. Some authors [12, 13, 14] believe that quality of delivery is also ensured by continuous allocation of funds for depreciation, regular services, and vehicle maintenance, in order to reduce the risk of sudden failures, jams, and delays in delivery, including the purchase of modern IT equipment that would improve the order processing and minimize the number of mistakes in the quantity and type of goods that are the subject of transport. The other analyzed indicators do not have a statistically significant impact.

The obtained results at the level of the entire sample of the WB coincide with the results of the studies done by Chaea [13], Dumitrache et al. [14], Cai et al. [12], etc., which emphasize transport costs, timely and complete delivery, and long-term relationships with customers (CRM) as the most important KPIs in the process of physical distribution of goods. The development of these indicators influences the ultimate goal of the physical distribution process that is reflected in the creation of a base of satisfied and loyal end users, based on operations according to the 7P concept. 
The indicator Condition of vehicles is less important to the performance of physical distribution, which is a surprising result given that some authors, e.g. Liao et al. [15], point to a strong correlation between vehicle quality as a KPI and timely and complete delivery. Institutional/regulatory factors do not have a statistically significant impact, as a result of the fact that they are external factors, the effect of which is difficult to measure, and they are difficult to influence.

With respect to the sub-samples at the level of the EU countries, the equation of physical distribution of consumer goods is as follows (Equation 2):

$$
\begin{aligned}
y= & -0.01+1.03 x_{1}+0.56 x_{2}-0.25 x_{3}+ \\
& +2.07 x_{4}-0.14 x_{5}
\end{aligned}
$$

where $y$ is the dependent variable (physical distribution of consumer goods), while the variable $x$ is the independent variable $\left(x_{1}\right.$ - transport costs; $x_{2}$ - quality of delivery; $x_{3}$ - condition of vehicles; $x_{4}$ - customer relations, and variable $x_{5}$ - institutional/regulatory factors). The most important indicators appear to be transport costs $(B=1.03)$, customer relations $(B=2.07)$, and quality of delivery $(B=0.56)$. The results are identical as at the level of the sample of the WB, whereby the statistically significant impact observed separately by indicators varies. The ratio between the WB/EU countries for the indicator Transport cost is $0.6 / 1.03$, for the Quality of delivery 0.46/0.56, and for Customer relations $1.28 / 2.07$.

In the sample of the countries that are in the process of joining the EU, two indicators dominate that are presented by the following Equation 3:

$$
y=6.843+0.99 x_{1}+0.69 x_{2}
$$

In the equation, $y$ is the dependent variable (physical distribution of consumer goods), while the variable $x$ is the independent variable, such as: $x_{1}$ - transport costs and $x_{2}$ - quality of delivery. The reason for the completely neglected impact of the remaining three indicators is the fact that in the transition countries, due to the relatively low standard of living and purchasing power, the indicators related to financial investments and their provision, such as transport costs $(B=0.99)$ and quality of delivery $(B=0.69)$, are regarded by employees as the most important predictors. Physical distribution improvement requires distribution centers and transport companies to raise additional funds for equipment modernization through investments and deductions from a portion of the profits in order to ensure timely and complete delivery on the one hand, while on the other hand their priority task is to optimize the costs through precise systematization of business responsibilities (proper economization), employment of professional and responsible people, introduction of IT support, etc.
Finally, satisfaction with the physical distribution of consumer goods reflects the satisfaction of end users, which can be represented by the following Equation 4:

$y=2.01 x_{1}-0.72 x_{2}+0.56 x_{3}$

In the equation, $y$ marks the loyalty of end users of transport services, while $x$ is the independent variable, such as: $x_{1}$ - timely delivery; $x_{2}$ - mistakes in the delivery; $x_{3}$ - flexibility. The equation illustrates that the satisfaction of end customers in the supply chain (retail stores) is directly proportional to timely delivery of goods $(B=2.01)$ and flexibility and extraordinary requirements in the transport $(B=0.56)$, and inversely proportional to the number of mistakes and delays $(\mathrm{B}=-0.72)$.

Disadvantages of the research relate to the restrictions of the analysis and research to only one type of transport in the Western Balkans. An objective reason for analyzing only the physical distribution process is the fact that this is the only form of transport of goods represented in all the countries of the region, providing the possibility to compare data. In supply chains of Serbia, Bosnia and Herzegovina, and Macedonia there is almost no supply of retail stores by waterways and rail routes, unlike Slovenia and Montenegro, and especially Croatia, with a developed network of navigable waterways linking the logistics centers and retail facilities. The limiting factor is also conducting research exclusively in the Western Balkans region, however, the inclusion of a large number of countries from the global market would require huge financial resources, knowledge of transport infrastructure and consumer habits in such countries, etc. In conducting the research, the problem was also the fact that business people from the region of the Western Balkans have no habit of participating in serious research, as shown by the fact that besides 312 completed surveys, 128 were left unfinished, so the results of these surveys were not considered in the testing and analysis. A shortcoming of the research is also the fact that it did not cover a positive correlation between price and quality of transport, i.e., whether end users will accept higher-quality physical distribution at higher prices or will they look for economically more cost-effective solutions at the expense of service quality. Such research would involve a different methodology and insights into the financial reports of transport companies and retailers, macroeconomic analysis of regions and countries, etc.

\section{CONCLUSION}

The need to research indicators of physical distribution of consumer goods in the supply chain in the Western Balkans stems from the fact that it is a growing sector of economic activity with limited research on the impact and importance of individual indicators regarding the quality, accurate and efficient transport 
and delivery of goods to end customers. The results of this research show which indicators have a statistically significant impact. At the level of the sample of the Western Balkans, the dominant indicators are transport costs, quality of delivery, and customer relations. By comparing equations at the level of the EU/ non-EU countries sample, it is evident that the least deviation is for the parameters of Transport costs (1.03/0.99) and the Quality of delivery of consumer goods $(0.56 / 0.69)$. However, the remaining parameters at the level of the non-EU countries sample have virtually no statistically significant impact on physical distribution. The reasons for such deviations are the following: a) the business environment of the non-EU countries is still insufficiently institutionalized and legislatively regulated, which indirectly reduces the importance of this indicator to the quality of distribution, b) lack of investment and funding, as well as the unstable macroeconomic and overall economic situation of the non-EU countries reflect on insufficient investment in vehicles and the marginalization of the impact of this indicator, etc.

Improvement of transport means that the managements of responsible companies in the supply chain should focus on the specified indicators and integrate them into their business strategies, as well as develop and optimize them. That also reflects the practical significance of this research. On the other hand, the research shows that such high-quality transport and delivery have a positive impact on satisfaction of customers, who remain loyal to their chosen transport companies and distribution centers.

Future research would imply expanding the analysis and making a comparison in the process of physical distribution of certain subcategories of consumer goods, such as: confectionery products, meat and meat-based products, chemicals and chemical products, milk and dairy products, bread, pastry and other cereal products, spices, tobacco, alcoholic and non-alcoholic beverages, etc. The analysis should include other countries, outside of the Western Balkans and in South East Europe, such as Hungary, Romania, Greece, etc. The data and indicators obtained on the basis of research conducted in these countries would complete the scientific review of road transport and delivery of consumer goods in the supply chains.

\section{Doc. dr RADENKO M. MARIĆ ${ }^{1}$}

E-mail: radenko.maric@ef.uns.ac.rs

Doc. dr DRAGAN ĐURANOVIĆ ${ }^{1}$

E-mail: djuranovic@ef.uns.ac.rs

Dr DANIELA NUŠEVA ${ }^{1}$

E-mail: nusevad@ef.uns.ac.rs

1 Univerzitet u Novom Sadu, Ekonomski Fakultet u Subotici Segedinski put 9-11, 24000 Subotica, Srbija

\section{KLUUČNI INDIKATORI FIZIČKE DISTRIBUCIJE ROBE: STUDIJA SLUČAJA ZAPADNOG BALKANA}

\section{REZIME}

Cilj ovog rada je da su unapredi proces fizičke distribucije robe široke potrošnje u regionu Zapadnog Balkana, kroz definisanje i analizu ključnih indikatora fizičke distribucije. Teorijskim istraživanjem su identificirani najvažniji indikatori koju utječu na proces fizičke distribucije, to su: troškovi transporta, kvaliteta isporuke, stanje voznog parka, odnosi s klijentima i institucionalno/ zakonodavni faktori. Provedeno je empirijsko istraživanje na uzorku od 166 ispitanika u distributivnim centrima i transportnim poduzećima i 146 krajnjih klijenata. Višestrukom regresionom analizom definiran je pojedinačni doprinos svakog od navedenih indikatora. Komparacija rezultata između zemalja Zapadnog Balkana koje su članice EU i zemalja u procesu pridruživanja EU, pokazala je postojanje statistički značajnih razlika u utjecaju navedenih pokazatelja. Na bazi dobivenih rezultata prezentirani su modeli fizičke distribucije robe široke potrošnje. Dobiveni rezultati ukazuju menadžmentu distributivnih centara i transportnih poduzeća koje indikatore treba razvijati kako bi se osigurala pravovremena i potpuna isporuka robe saglasno konceptu 7P i time stvorila baza zadovoljnih i lojalnih krajnjih korisnika usluge transporta. Preporuke za buduća istraživanja navedene su u radu.

\section{KLUUČNE RIJEČI}

cestovni prijevoz robe; distributivni centri; fizička distribucija robe; maloprodaja;

\section{REFERENCES}

[1] Cristopher M. Logistics and Supply Chain Management. New York: Pearson Education, 2016.

[2] Eckhardta J, Rantalab J. The role of intelligent logistics centres in a multimodal and cost-effective transport system. Procedia - Social and Behavioral Sciences. 2012;48: 612-621. doi:10.1016/j.sbspro.2012.06.1039.

[3] Manders JHM, Caniëls MCJ, Ghijsen PWT. Exploring supply chain flexibility in a FMCG food supply chain. Journal of Purchasing and Supply Management. 2016;22(3): 181-195. doi:10.1016/j.pursup.2016.06.001.

[4] Barick R, Jakubiec M. Marketing Logistics. Acta Academica Karviniensia. 2013;4: 5-12.

[5] Rodrigues VS, Stantchev D, Potter A, Naim M, Whiteing A. Establishing a transport operation focused uncertainty model for the supply chain. International Journal of Physical Distribution \& Logistics Management. 2008;38(5): 388-411. doi:10.1108/09600030810882807

[6] Higgins CD, Ferguson M, Kanaroglou PS. Varieties of Logistics Centres: Developing a Standardized Typology and Hierarchy. Journal of the Transportation Research Board. 2012;2288: 1-20. doi: https://doi. org/10.3141/2288-02

[7] Končar J, Leković S. The multichannel strategies in terms of internationalization of retailers. The Annals of the Faculty of Economics in Subotica. 2015;51(33): 361-371. 
[8] Antủn JP, Lozano A, Alarcón R, Granados F, Guarneros $L$. The physical distribution of goods in a megalopolis: Strategies for policies on the location of logistics facilities within the Central Region of Mexico. Procedia - Social and Behavioral Sciences. 2010;2(3): 6130-6140. doi:10.1016/j.sbspro.2010.04.025

[9] Oke A, Gopalakrishan M. Managing disruptions in supply chains: A case study of a retail supply chain. International Journal of Production Economics. 2009;118(1): 168-174. doi: 10.1016/j.ijpe.2008.08.045.

[10] Ivanov D, Harlt R, Dolgui A, Pavlov A, Sokolov B. Integration of aggregate distribution and dynamic transportation planning in a supply chain with capacity disruptions and the ripple effect consideration. International Journal of Production Research. 2015;53(23): 69636979. doi:10.1080/00207543.2014.986303.

[11] Guan W, Rehme J. Vertical integration in supply chains: driving forces and consequences for a manufacturer's downstream integration. Supply Chain Management: An International Journal. 2012;17(2): 187-201, doi:10.1108/13598541211212915.

[12] Cai S, Jun M, Yang Z. Implementing supply chain information integration in China: The role of institutional forces and trust. Journal of Operations Management. 2010;28(3): 257-268. doi: 10.1016/j. jom.2009.11.005.

[13] Chae B. Developing key performance indicators for supply chain: an industry perspective. Supply Chain Management: An International Journal. 2009;14(6): 422-428. doi:10.1108/13598540910995192.

[14] Dumitrache C, Kherbash O, Liviu Mocan M. Improving Key Performance Indicators in Romanian Large Transport Companies. Procedia - Social and Behavioral Sciences. 2016;221: 211-217. doi:10.1016/j. sbspro.2016.05.108.

[15] Liao CJ, Lin Y, Shih SC. Vehicle routing with cross-docking in the supply chain. Expert Systems with Applications. 2010;37(10): 6868-6873. doi:10.1016/j. eswa.2010.03.03 